\title{
Concentrations and Radiation Hazard Indices of Naturally Radioactive Materials for Flour Samples in Baghdad Markets
}

\author{
Ban Sabah Hameed ${ }^{1}$ \\ Farah Faris Kaddoori ${ }^{1 *}$ \\ Wijdan Thamer Fzaa ${ }^{2}$
}

\begin{abstract}
${ }^{1}$ Department of Physics, College of Science for Women, University of Baghdad, Baghdad, Iraq.
${ }^{2}$ Al-Nahrain Nonrenewable Energy Research Center

"Corresponding author: banalqazaz@yahoo.com, farahfaris84@gmail.com", wijdanthamer974@gmail.com

"ORCID ID: https://orcid.org/0000-0002-4220-1543, https://orcid.org/0000-0002-2103-8177", https://orcid.org/00000001-9667-4285
\end{abstract}

Received 5/1/2020, Accepted 22/6/2020, Published Online First 21/2/2021, Published 1/9/2021

This work is licensed under a Creative Commons Attribution 4.0 International License.

\begin{abstract}
:
In the present work, Uranium $\left({ }^{238} \mathrm{U}\right)$, Thorium $\left({ }^{232} \mathrm{Th}\right)$ and Potassium $\left({ }^{40} \mathrm{~K}\right)$ specific activity concentration in $(\mathrm{Bq} / \mathrm{kg})$ was measured in five different types for wheat flours that are available in the Iraqi markets. The gamma spectrometry method with an $\mathrm{NaI}(\mathrm{Tl})$ detector has been used for radiometric measurements. Calculations of radium equivalent activity, annual effective dose equivalent, external hazard index $\left(\mathrm{H}_{\mathrm{ex}}\right)$, internal hazard index $\left(\mathrm{H}_{\mathrm{in}}\right)$, representing gamma index and gamma dose rate in all flour samples were $17.98132 \mathrm{~Bq} / \mathrm{kg}, 0.0100334,0.04502,0.04857,0.06872,0.125883$ and 8.181244 respectively. It is found that the average of specific activity concentration of wheat flour samples for ${ }^{238} \mathrm{U},{ }^{232} \mathrm{Th}$ and ${ }^{40} \mathrm{~K}$ are $7.4564 \mathrm{~Bq} / \mathrm{kg}, 6.27962 \mathrm{~Bq} / \mathrm{kg}$ and $20.0658 \mathrm{~Bq} / \mathrm{kg}$ respectively. This study proves that the natural radioactivity and radiation hazard indices were lower than the safe.
\end{abstract}

Key words: Environmental, Pollution, Radioactivity, Wheat flour.

\section{Introduction:}

Because of geographical and geological conditions, the natural radionuclide concentrations in environmental samples can be significantly various. Natural radioactivity can be classified into two types, cosmogenic and primordial, named naturally occurring radioactive materials, commonly mentioned as (NORM). Some instances of natural radioisotopes are potassium isotopes ${ }^{40} \mathrm{~K}$, uranium $\left({ }^{238} \mathrm{U}\right.$ and glycolysis chain), and thorium $\left({ }^{232} \mathrm{Th}\right.$ and glycolysis series). These radionuclides are generally available in air, soil, and water in diverse magnitudes, in addition to their long- lasting period (for about 1010 years) (1-3). In order to provide enough food to the increasing populations, several states have utilized phosphate fertilizers; these activities have triggered a substantial alteration in potassium in the soil, which makes significant changes to these agricultural activities. By means of the soil and phosphate utilizers, natural radioactive elements transfer through the food chain to humans. In order to avoid consumer vulnerability to radiation, it was substantial to measure the radioactivity of some food samples in order to identify the anticipated radiation doses. As well-known, potassium is deemed to be one of the bulk substantial fundamental elements admitted into the cellular tissues, so ${ }^{40} \mathrm{~K}$ is one of the bulk substantial physical radionuclides (4). About $87 \%$ of the radiation dose sucks by humanity is from natural radiation according to UNSCEAR 2000 (5). Wheat flour is considered as one of the substantial foods in Iraqis daily lives. It is appropriate to compose a national baseline of radioactivity exposure from various type wheat flour samples available in Iraq markets. Wheat flour is produced from grinding wheat used for human consumption. Wheat flour has been a fundamental staple to human presence across the centuries and is currently the more broadly expendable staple food. Additionally, several studies have been performed worldwide to inquire the natural radionuclides in food consumer in various areas of the world (6-9). By spectroscopic analysis, the concentration of natural radionuclides $\left({ }^{40} \mathrm{~K},{ }^{232} \mathrm{Th},{ }^{226} \mathrm{Ra}\right)$ is computed in diverse foods for human depreciation in the Abyan Delta in Yemen and it was found that the modified concentrations of radionuclides of ${ }^{226} \mathrm{Ra},{ }^{232} \mathrm{Th}$, and

${ }^{40} \mathrm{~K}$ in the selected specimens were $1.11 \pm 0.08$, $1.00 \pm 0.05$ and $108.86 \pm 3.49$, respectively. It was 
remarked that the modified concentration of ${ }^{40} \mathrm{~K}$ activity in foods was substantially of a superior activity to the modified concentrations of ${ }^{226} \mathrm{Ra}$ and ${ }^{232} \mathrm{Th}$ in all the samples (10-12).

The aim of the current work is measuring natural radioactivity concentrations for flour samples; Besler, Zer, Paten, Flour provided by government and barley in the local markets of Baghdad city in 2019, three samples of each type for flour were taken. Also, it calculated radium equivalent activities, annual effective dose equivalent, external and internal menace indices, representing extent index, and the gamma dose rate using a gamma spectrometry, NaI ( $\mathrm{Tl})$ detector. Then, it estimated the radioactivity and its effect on human health. This study is necessary in the standpoint radiation protection and discusses natural radioactive elements in food coverage by the humans.

\section{Material and Methods:}

\section{Specific activity concentration}

The specific activity concentration is the relationship between the mass of the material and its radiation efficiency in $\mathrm{Bq} / \mathrm{Kg}$, which is the number of anomalies that occur per second in radionuclide, it is given by Eq. $1(13,14)$ :

$\mathrm{S} . \mathrm{A}=\mathrm{C}=\mathrm{A} / \mathrm{M}$

Terms A is the activity which is identified directly from the screen of the system in $\mathrm{Bq}, \mathrm{M}$ is the mass of sample in $\mathrm{Kg}$.

Samples like Besler, Zer, Paten, Flour are provided by government and barley in the local markets of Baghdad city in 2019 .Gamma spectroscopy with Sodium iodide (NaI (Tl)) (3" X 3 ") detector was adjusted for a period of 3600 seconds, and completely insulated by lead shield (13) used to determine NORM concentrations, in flour powdered samples. The weight of each samples are is $\mathrm{Kg}$. Because the $\mathrm{NaI}(\mathrm{Tl})$ detector is characterized by poor efficiency in energy resolution, radionuclides daughter was selected to determine radioactivity concentration for two series of ${ }^{238} \mathrm{U}$ and ${ }^{232} \mathrm{Th}$ where nuclide ${ }^{226} \mathrm{Ra}$ was chosen to indicate the radioactivity for a series of ${ }^{238} \mathrm{U}$, which have been determined through radioactive isotope ${ }^{214} \mathrm{~Pb}(352 \mathrm{keV})$. Moreover, a series of ${ }^{232} \mathrm{Th}$ through a radioactive isotope ${ }^{212} \mathrm{~Pb} \quad(239 \mathrm{keV})$ was determined. As regards ${ }^{40} \mathrm{~K}(1460.8 \mathrm{keV})$, it can be detected directly by the detector $(4,13,14)$.

\section{Radium Equivalent Activity $\left(\mathbf{R a}_{\text {eq }}\right)$}

Radium equivalent activity $\mathrm{Ra}_{\mathrm{eq}}$ which is the equivalent concentration value of the radium element is used to study the risk concentration caused by ${ }^{226} \mathrm{Ra},{ }^{232} \mathrm{Th}$ and ${ }^{40} \mathrm{~K} \quad(\mathrm{~Bq} / \mathrm{Kg})$. In addition, the radiation hazards associated with them were taken into account and can be calculated from the following relationship as show in Eq.2 (15).

$\mathrm{Ra}_{e q}=\mathrm{C}_{(R a)}+1.43 \mathrm{C}_{(\mathrm{Th})}+0.077 C_{(K)} \quad 2$

Where $\mathrm{C}_{\text {(Ra) }}, \mathrm{C}_{\text {(Th) }}$ and $\mathrm{C}_{(\mathrm{K})}$ represented radioactivity concentration in $(\mathrm{Bq} / \mathrm{Kg})$ for ${ }^{238} \mathrm{U}$, ${ }^{232} \mathrm{Th}$ and ${ }^{40} \mathrm{~K}$, respectively.

\section{Annual Effective Dose Equivalent (AEDE)}

Dose equivalent receipt by the external member was computed from the absorbed dose rate through implementing the dose conversion of $0.7(\mathrm{~Sv} / \mathrm{Gy})$ and the internal and external occupancy factor will be $0.2(5 / 24)$ and $0.8(19 / 24)$, respectively $(13,15)$. AEDE is determining by the Eqs. 3 and 4 .

$$
\begin{aligned}
& \text { AEDE (external) } \\
& (\mathrm{mSv} / \mathrm{y})=\text { Absorbed dose }(\mathrm{nGy} / \mathrm{h}) \times 8760(\mathrm{~h} / \\
& \text { y)x } 0.7(\mathrm{~Sv} / \mathrm{Gy}) \times 0.2 \times 10^{-6} 3 \\
& \text { AEDE (internal) } \\
& (\mathrm{mSv} / \mathrm{y})=\text { Absorbed dose }(\mathrm{nGy} / \mathrm{h}) \times 8760(\mathrm{~h} / \\
& \text { y) } x 0.7(\mathrm{~Sv} / \mathrm{Gy}) \times 0.8 \times 10^{-6} 4
\end{aligned}
$$

\section{External Hazard Index $\left(\mathrm{H}_{\mathrm{ex}}\right)$}

This hazard can be quantified by the external hazard index $\left(\mathrm{H}_{\mathrm{ex}}\right)(13,15,16)$. which is determined by Eq. 5:

$$
\mathrm{H}_{\mathrm{ex}}=\frac{C_{R a}}{370}+\frac{C_{T h}}{259}+\frac{C_{K}}{4810}
$$

The value of this index should be lower than one unit for the radiation hazard to be minimal. $\mathrm{H}_{\mathrm{ex}}$ equals to unity that is symmetrical for the high limit of $\mathrm{Ra}(\mathrm{eq}) 370(\mathrm{~Bq} / \mathrm{Kg})(13)$.

\section{Internal Hazard Index $\left(\mathrm{H}_{\text {in }}\right)$}

This hazard can be quantified by the internal hazard index $\left(\mathrm{H}_{\mathrm{in}}\right)(13,15,16)$. This is given by Eq. 6:

$$
\mathrm{H}_{\mathrm{in}}=\frac{C_{(R a)}}{185}+\frac{C_{(T h)}}{259}+\frac{C_{(K 0)}}{4810}
$$

The value of this index should be lower than one unit for the radiation hazard to be minimal.

\section{Representative Gamma Index $\left(\mathbf{I}_{\gamma \mathbf{r}}\right)$}

The representative gamma index is given by Eq.7 (17):

$$
\mathrm{I}_{(\gamma \mathrm{r})}=\frac{C_{(R a)}}{150}+\frac{C_{(T h)}}{100}+\frac{C_{(K)}}{1500}
$$

Value of $\mathrm{I}_{\gamma \mathrm{r}} \leq 1$ complies to an annual effective dose, of lower than or equal to $1.0(\mathrm{mSv})$, while the $\mathrm{I}_{\gamma \mathrm{r}} \leq 0.5$ complies to annual effective dose lower or equal to $0.3(\mathrm{mSv})(17,5)$ 


\section{Gamma Dose Rate}

The gamma dose rate in the external air at $1.0 \mathrm{~m}$ above the ground level can be calculated using Eq. 8 (17).

$\mathrm{D}(\mathrm{nGy} / \mathrm{h})=0.462 \mathrm{C}_{(\mathrm{Ra})}+0.621 \mathrm{C}_{(\mathrm{Th})}+0.0417 \mathrm{C}_{(\mathrm{K})}$ 8

\section{Results and Discussion:}

${ }^{238} \mathrm{U},{ }^{232} \mathrm{Th}$ and ${ }^{40} \mathrm{~K}$ are naturally occurring elements. Their nuclei of radioactive elements are unstable, meaning they are transformed into other elements, typically by emitting particles. Uranium decays mainly by alpha-particle emission to become nonradioactive lead and it has very long half-lives. In the case of ${ }^{40} \mathrm{~K}$, it undergoes beta decay to stable species $\left({ }^{40} \mathrm{Ca}\right)$ and for ${ }^{232} \mathrm{Th}$ they undergo alphadecay to stable species $\left({ }^{228} \mathrm{Ra}\right)(13)$. The specific activity concentration due to ${ }^{238} \mathrm{U},{ }^{232} \mathrm{Th}$ and ${ }^{40} \mathrm{~K}$ in various types of wheat flour samples has be measured as shown in Table 1 and Fig.1. The specific activity concentration of ${ }^{40} \mathrm{~K}$ was found in the range of $22.587 \mathrm{~Bq} / \mathrm{Kg}$ in barley flour to the $16.468 \mathrm{~Bq} / \mathrm{Kg}$ in flour provided by government with an average value $20.0658 \mathrm{~Bq} / \mathrm{Kg}$, ${ }^{232} \mathrm{Th}$ from 9.769 $\mathrm{Bq} / \mathrm{Kg}$ in Barley flour to $4.3101 \mathrm{~Bq} / \mathrm{Kg}$ in zer flour with an average $6.27962 \mathrm{~Bq} / \mathrm{Kg}$ and ${ }^{238} \mathrm{U}$ from $9.329 \mathrm{~Bq} / \mathrm{Kg}$ in flour provided by government to $6.109 \mathrm{~Bq} / \mathrm{Kg}$ in zer flour. The results obtained shows that, the concentration of specific activity for ${ }^{238} \mathrm{U},{ }^{232} \mathrm{Th}$ and ${ }^{40} \mathrm{~K}$ in all samples for flour was lower than the recommended limit of UNSCEAR 2000 which is 30,45 and $420 \mathrm{~Bq} \cdot \mathrm{kg}^{-1}$, respectively (5). The value of radium equivalent activities, annual effective dose equivalent, external and internal menace indices, representing extent index, and the gamma dose rate for all flour samples are listed in Table 2. The maximum value of radium equivalent activities, annual effective dose equivalent, external and internal menace indexes representing level index, and the gamma dose rate was found in barley flour sample and the minimum value of these indexes was found in zer flour sample. The results was lower than the recommended limit of UNSCEAR 2013 (18) which is $0.17 \mathrm{mSv} \mathrm{y}^{-1}$ for ${ }^{40} \mathrm{~K}$ and $0.12 \mathrm{mSv} \mathrm{y}^{-1}$ for Uranium and Thorium. High intake of ${ }^{232} \mathrm{Th},{ }^{238} \mathrm{U}$, ${ }^{40} \mathrm{~K}$ and their decay products may lead to harmful effects in human beings. An exposure of about 0.1 $\mathrm{mg} . \mathrm{Kg}^{-1}$ form body weight of soluble natural Uranium, Thorium and Potassium results in transient chemical damage to the kidneys (19). All the results obtained from this study are in agreement with the previous studies $(4,20)$.

Table 1. The specific activity concentration for ${ }^{232} \mathrm{Th},{ }^{238} \mathrm{U}$, and ${ }^{40} \mathrm{~K}$ isotopes in all samples.

\begin{tabular}{ccccc}
\hline $\begin{array}{c}\text { Samples } \\
\text { number }\end{array}$ & $\begin{array}{c}\text { Samples } \\
\text { name }\end{array}$ & \multicolumn{3}{c}{$\begin{array}{c}\text { The specific activity } \\
\text { concentration }(\mathbf{B q} / \mathbf{K g})\end{array}$} \\
\cline { 3 - 5 } & & ${ }^{232} \mathbf{T h}$ & ${ }^{238} \mathbf{U}$ & ${ }^{40} \mathbf{K}$ \\
1 & Besler flour & 4.796 & 6.309 & 18.486 \\
2 & Zer flour & 4.3101 & 6.109 & 20.302 \\
3 & Paten flour & 5.791 & 7.214 & 22.486 \\
4 & Flour provide & 6.732 & 9.329 & 16.468 \\
& by & & & \\
5 & government & & & \\
5 & Barley flour & 9.769 & 8.321 & 22.587 \\
Average & & 6.27962 & 7.4564 & 20.0658 \\
\hline
\end{tabular}

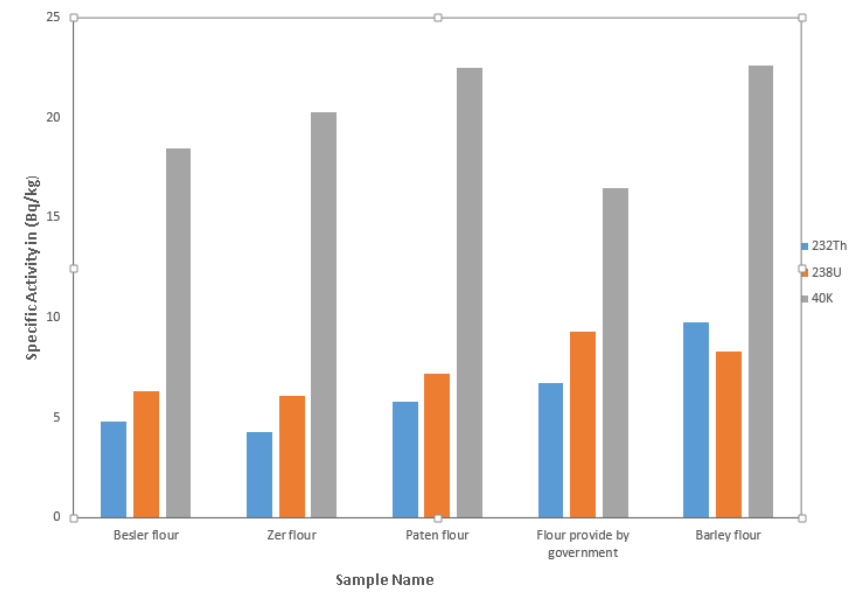

Figure 1. Specific Activity concentration for ${ }^{238} U$, ${ }^{232} \mathrm{Th}$ and ${ }^{40} \mathrm{~K}$ in $(\mathrm{Bq} / \mathrm{Kg})$

Table 2.Hazard indices in all samples are studies.

\begin{tabular}{cccccccc}
\hline Samples & $\begin{array}{c}\mathbf{R a}_{\text {eq }} \\
\mathbf{( B q / k g})\end{array}$ & $\mathbf{D}(\mathbf{n G y} / \mathbf{h})$ & $\mathbf{H}_{\text {ex }}$ & $\mathbf{H}_{\text {in }}$ & $\mathbf{I}_{(\mathbf{y r})}$ & $\begin{array}{c}\text { AEDE } \\
\text { external }\end{array}$ & $\begin{array}{c}\text { AEDE } \\
\text { internal }\end{array}$ \\
\hline Besler flour & 14.5907 & 6.66394 & 0.03941 & 0.05646 & 0.102344 & 0.008172 & 0.032691 \\
Zer flour & 13.8357 & 6.34552 & 0.03737 & 0.05388 & 0.097362 & 0.007782 & 0.031129 \\
Paten flour & 17.22655 & 7.86674 & 0.04653 & 0.06602 & 0.120994 & 0.009647 & 0.038591 \\
$\begin{array}{c}\text { Flour provide } \\
\text { by government }\end{array}$ & 20.2238 & 9.17728 & 0.05462 & 0.07984 & 0.140492 & 0.011255 & 0.04502 \\
Barley flour & 24.02987 & 10.85272 & 0.06490 & 0.08739 & 0.168221 & 0.013309 & 0.053239 \\
Average & 17.98132 & 8.181244 & 0.04857 & 0.06872 & 0.125883 & 0.0100334 & 0.040134 \\
\hline
\end{tabular}


Fig. 2 shows the average value of $\mathrm{Ra}_{\mathrm{eq}}$ of gamma dose rate for all samples were determined using Eq.2. The maximum value of gamma dose rate was $24.02987 \mathrm{~Bq} / \mathrm{Kg}$ in barley flour and the minimum value of radium equivalent activities was 17.98132 $\mathrm{Bq} / \mathrm{Kg}$ in zer flour sample.

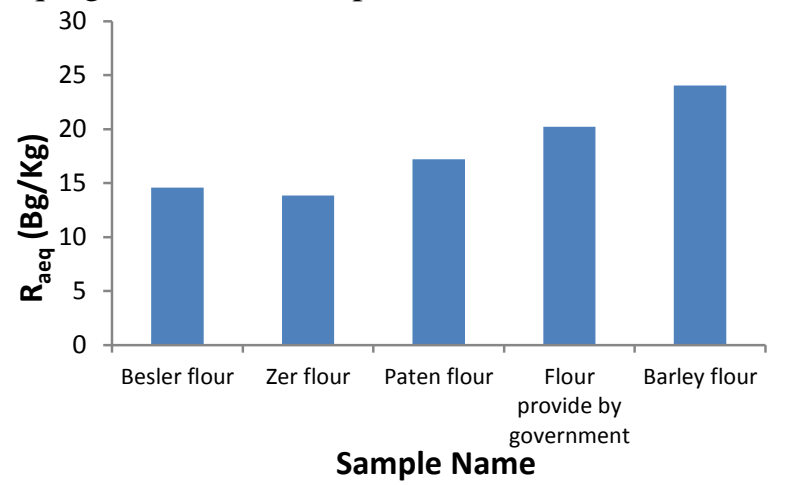

Figure 2. The $\mathbf{R a}_{\mathrm{eq}}$ for flour samples.

The average values of the (AEDE), calculated using Eqs.3,4 in units of $\mathrm{mSv} / \mathrm{y}$. by using 0.8 for the outdoor occupy factor, which implies $20 \%$ of time is spent outdoors, while for the indoor occupy factor 0.2 is used, which is suggested by UNSCEAR 2013 respectively (18). The average value of the AEDE reason to wilderness gamma radiation internal and external received for flour models was 0.04013 and 0.01003 (mSv/y). The maximum value for AEDE internal was 0.05324 $(\mathrm{mSv} / \mathrm{y})$ in barley flour samples and for AEDE external was $0.01331(\mathrm{mSv} / \mathrm{y})$ in barley flour samples. The minimum value for AEDE internal was $0.03113(\mathrm{mSv} / \mathrm{y})$ in the zer flour samples and for AEDE external was was $0.00778(\mathrm{mSv} / \mathrm{y})$ in the zer flour samples, as shows in Figs. 3 and 4.

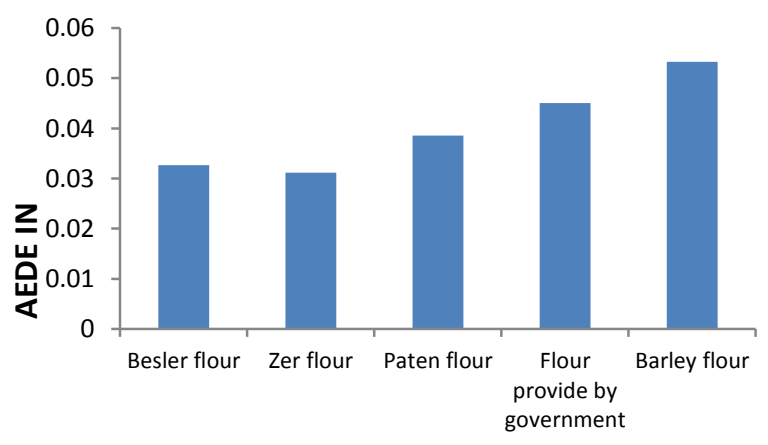

Sample Name

Figure 3. The AEDE (internal) for flour samples

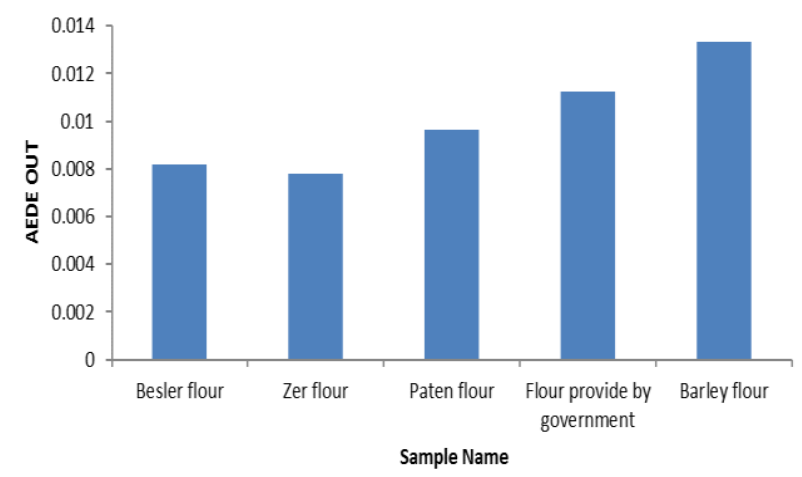

Figure 4. The AEDE (external) for flour samples.

Figures 5and 6 shows the average value of the $\mathrm{H}_{\mathrm{ex}}$ and $\mathrm{H}_{\mathrm{in}}$, which is 0.04857 and 0.0687 respectively. By using Eqs. 5, 6 the maximum value of $\mathrm{H}_{\mathrm{ex}}$ was 0.0649 in barley samples and the minimum value was 0.03737 in zer samples. And the maximum value of $\mathrm{H}_{\text {in }}$ was 0.08739 in barley samples and the minimum value was 0.05388 in zer samples. The all result values for $\mathrm{H}_{\mathrm{ex}}$ and $\mathrm{H}_{\mathrm{in}}$ have the regular extent and it's under unity.

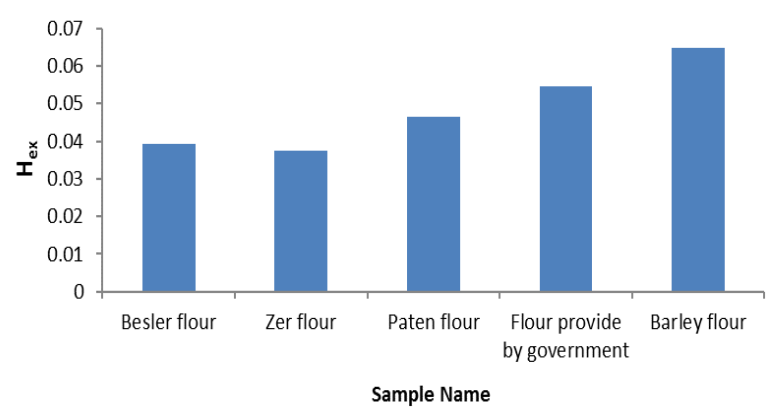

Figure 5. The external and hazard indexes for flour samples.

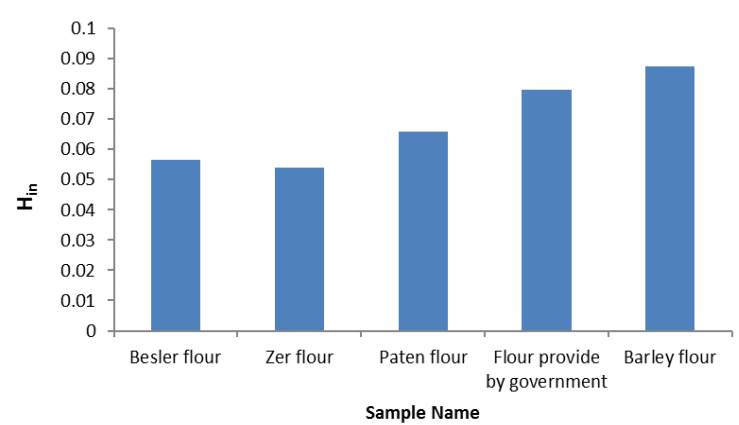

Figure 6. The internal and hazard indexes for flour samples.

The average value of the represented extent index I $\gamma \mathrm{r}$ for all samples was 0.12588 specifies by using eq. 7 whereas the maximum value was 0.1682 in barley samples, and the minimum value was 0.09736 in zer samples. Fig.7 describes the 
represented extent indexes, I $\gamma \mathrm{r}$ and the dose rate in nGyh.

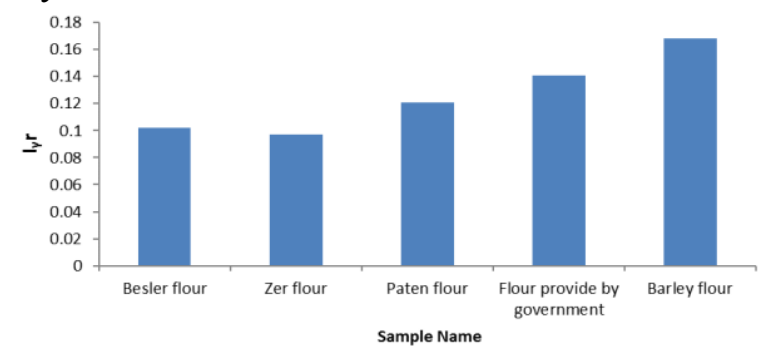

Figure 7. The level index I $\gamma \mathrm{r}$ indexes for flour samples.

Fig. 8 shows the average value of the gamma dose rate (D) for the all samples were existed to be 8.18124(nGy/h) that was calculate used eq.8. The maximum value was $10.85272(\mathrm{nGy} / \mathrm{h})$ for barley flour and the minimum value was $6.34552(\mathrm{nGy} / \mathrm{h})$ for zer flour.

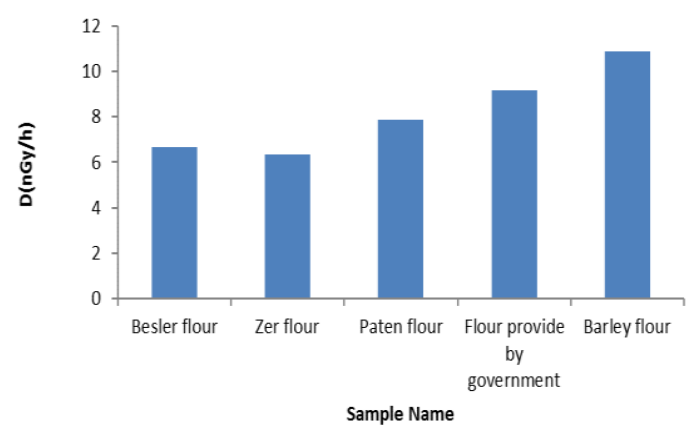

Figure 8. The gamma dose rate indices for flour samples.

Figur 9 represents an experimental relationship between the radium equivalent activity and the internal hazard index, where it was observed that the $\mathrm{H}_{\text {in }}$ increased directly with the $\mathrm{Ra}_{\mathrm{eq}}$

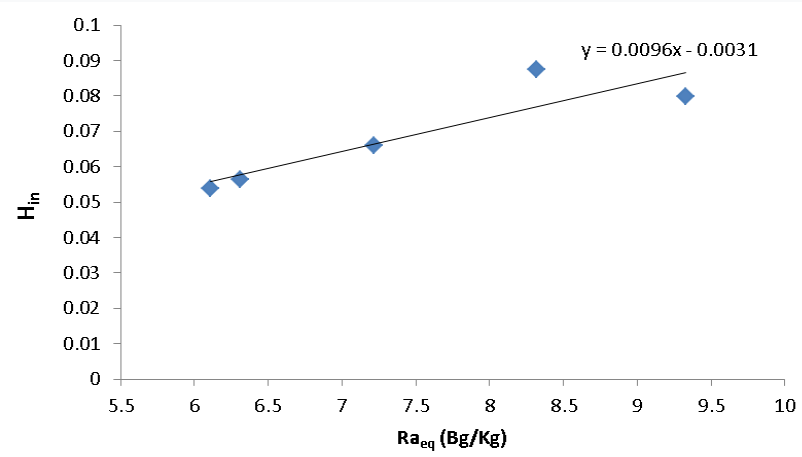

Figure 9. The relationship between $\mathrm{Ra}_{\mathrm{eq}}$ and $\mathrm{H}_{\mathrm{in}}$.

\section{Conclusions:}

As commented on before, $87 \%$ of the radiation dose is due to natural radiation sources .Essential shareholders existed by the present work are ${ }^{238} \mathrm{U}$ and ${ }^{232} \mathrm{Th}$, that have activities in the same order as in the literature for ${ }^{226} \mathrm{Ra}$ and nearly twice as high for ${ }^{232} \mathrm{Th}$. The world average values of ${ }^{238} \mathrm{U},{ }^{232} \mathrm{Th}$ and ${ }^{40} \mathrm{~K}$ concentrations indicated for natural background areas are 30,45 and $420 \mathrm{~Bq} \cdot \mathrm{Kg}^{-1}$, respectively. The result values found are lower than the average values. Due to increasing employment of phosphate fertilizers in agriculture, potassium substance in soils can be changed and conveyed via food chain to man. As the metabolic balance maintains the ${ }^{40} \mathrm{~K}$ body level irrespective of intake quantities, since the metabolic balance sustain the ${ }^{40} \mathrm{~K}$ body level regardless of intake quantities, so the quantity of ${ }^{40} \mathrm{~K}$, which is $1.17 .10^{-4}$ of the natural plethora, will be also approximately constant. The annual ${ }^{40} \mathrm{~K}$ equivalent dose in tissues of the body is $165 \mu \mathrm{Sv}^{-1} \mathrm{y}^{-1}$ for adults and the total ${ }^{40} \mathrm{~K}$ effective dose from inhalation and ingestion is $170 \mu \mathrm{Sv}(5)$. Because of this, there is no trouble in swallowing cereal flour providing the activities levels existed in the present work.

\section{Authors' declaration:}

- Conflicts of Interest: None.

- We hereby confirm that all the Figures and Tables in the manuscript are mine ours. Besides, the Figures and images, which are not mine ours, have been given the permission for republication attached with the manuscript.

- Ethical Clearance: The project was approved by the local ethical committee in University of Baghdad.

\section{References:}

1. Khalid HM, Soaad AE , Zina JR. Natural Radioactivity of Soil Samples from the Abu SakhirNajaf (Iraq) by Using Gamma Spectroscopy. ETJ. 2016; 41-48.

2. Rejah B. Specific Activities of Natural Radionuclides and Annual Effective Dose Due to the Intake of Some Types of Children Powdered Milk Available in Baghdad Markets Baghdad. Baghdad Sci. J. 2017; 14 (3).

3. Aswood M, Salih A, Al Musawi M. Long-lived gamma-ray measurement in soil samples collected from city central of Al-Diwaniyah, J Phys Conf Ser. 2019; 1234(1).

4. Scheibel V, Appoloni C, Schechter H. Natural radioactivity traces in South-Brazilian cereal flours by gamma-ray spectrometry. J Radioanal Nucl Chem. 2006; 270(1):163-165.

5. UNSCEAR United Nations Scientific Committee on the effect of Atomic Radiation. Sources, Effect, and Risks of Ionizing Radiation" Report to the general Assembly with Scientific Annexes, Vol 1, United Nations, New York; 2000. 
6. Jibiri N, Okusanya A. Radionuclide contents in food products from domestic and imported sources in Nigeria. J Radiol Prot. 2008; 28:405-413.

7. Ababneh ZQ, Alyassin AM, Aljarrah KM, Ababneh AM. Measurement of natural and artificial radioactivity in powdered milk consumed in Jordan and estimates of the corresponding annual effective dose. Radiat Prot Dosim .2010; 138(3):278-283.

8. Desimoni J, Sives F, Errico L, Mastrantonio G, Taylor M A. Activity levels of gamma-emitters in Argentinean cow milk. J Food Compost Anal. 2009; 22: $250-253$.

9. El-Gamal H, Maher H., Emran S. Evaluation of natural radioactivity levels in soil and various foodstuffs from Delta Abyan, Yemen. J Radiat Res Appl Sci. 2019; 12(1): 226-233.

10. Rejah A. Specific Activities and Annual Effective Dose of Natural Radionuclides Due to the Intake of Some Types of Sugar Available in Baghdad Markets. AJPA. 2017; 5(2): 20-23.

11. Rejah A, Alameer N, Kadim W, Murad S. Estimate Level of Radon Concentration for Drinking Water in Some Regions of Baghdad City. Arab J Sci Eng. 2018; 43 (7): 3831-3835.

12. Morad A, Mahdi R, Rejah A. Radon Concentration and the Annual Effective Dose in the Soil Samples of the Midland Refineries Company - Doura - Baghdad - Iraq. IJSR. 2017; 6(8): 1513 -1516.

13. IAEA, International Atomic Energy Agency, Measurement of Radionuclides in Food and Environment, a Guidebook, Technical Reports. 1989; 295 (230)
14. TholkappianM, Chandrasekaran A, Chandramohan N, Harikrishnan N, Ravisankar R. Determination of Radioactivity Levels and Radiation Hazards in Coastal Sediment Samples of Chennai Coast, Tamilnadu, India using Gamma Ray Spectrometry with Statistical Approach. J Radiat Nucl App. 2018; 3(3): 171-182.

15. Maitham S. Radiation Hazard Index of Common Imported Ceramic Using for Building Materials in Iraq. Aust J Basic Appl Sci. 2017; 11(10): 94-102.

16. Ban S, Rajah B, Muter S. Study the Concentration of Naturally Occurring Radioactive Materials in the Samples of Rice and Salt in Baghdad Governorate. ANJS. 2016; 19 (1):104-109.

17. Sozan T, Lwise G. Determination of specific activity of 226Ra, 232Th and 40K for assessment of radiation hazards from Turkish plumicesamples. J Environ Radioact. 2007; 2 (3): 122-130.

18. UNSCEAR United Nations Scientific Committee on the effect of Atomic Radiation. Source , Effect, and Risks of Ionizing Radiation Report to the general Assembly with Scientific Annexes, United Nations ,New York; Vol 1, 2013,1(A).

19. UNSCEAR United Nations Scientific Committee on the effect of Atomic Radiation. Source , Effect, and Risks of Ionizing Radiation Report to the general Assembly with Scientific Annexes, United Nations;2017.

20. Abojassim A, Al-Gazaly H, Kadhim S. 238U, 232Th and $40 \mathrm{~K}$ in wheat flour samples of Iraq markets. Ukr. Food J. 2014; 3(3).

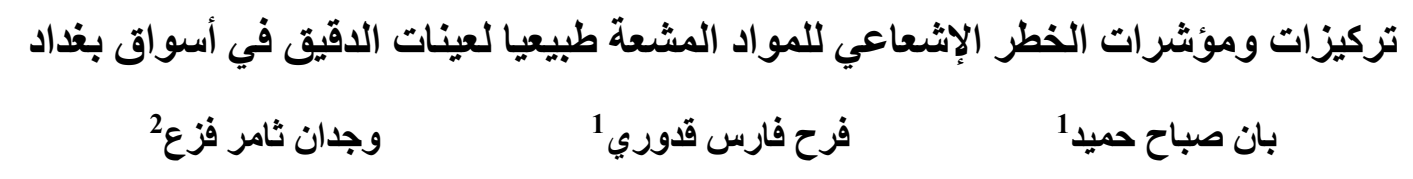

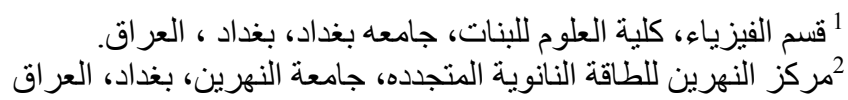

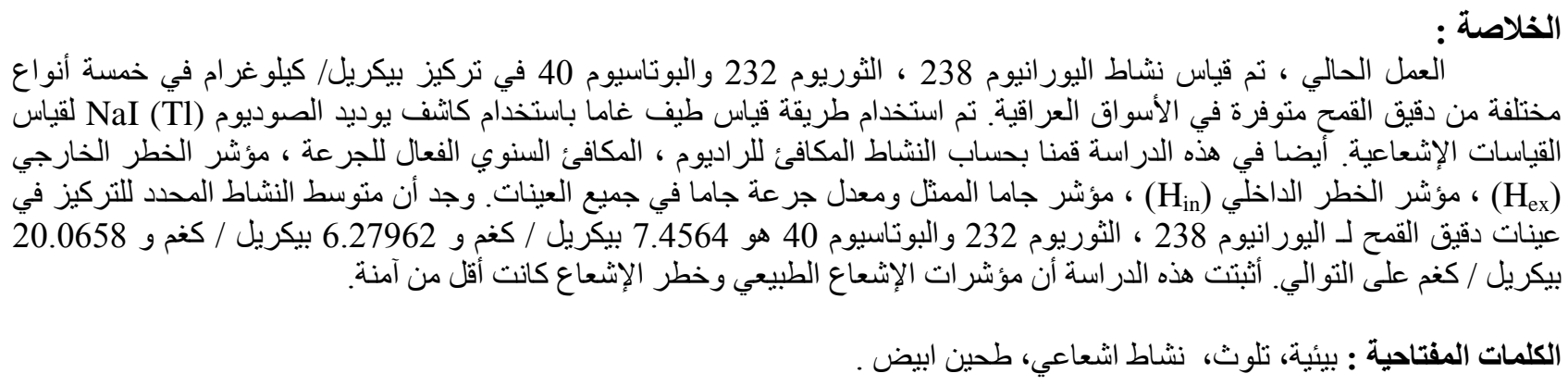

